\title{
The Narrative Emphasis on the Power of the Imagination in The Mill on the Floss: A Critical Analysis
}

\author{
Ibrahim Yekini* \\ Université d'Abomey, Calavi
}

*Corresponding Author: Ibrahim Yekini, Université d' Abomey, Calavi

\begin{abstract}
This critical research work aims at investigatingThe Mill on the Floss, one of George Eliot's novel which dramatizes the difficulties of the main character, Maggie Tulliver. Those difficulties are related to her status of middle social class in the 19th century conservative English Society. The novel is a tale of the relationship that exists between Maggie and her brother Tom and exposes the protagonist's failure in conforming to the norms of the patriarchal society she lives in. This article highlights the power of the imagination of the author.
\end{abstract}

Keywords: Imagination, Pain, Family, Tragedy, Social Norms, Passion

\section{INTRODUCTION}

George Eliot's The Mill on the Floss indicates the scope and vigour of the author's power of imagination. In this regards, The Mill on the Floss is a deep insight into human passion and psyche, an examination of motives and principles assorted with principles and philosophy likely to guide humanity out of the squalid oppressive conditions created by social norms, ideologies and religions.

This article is a psychological analysis of the protagonist of the novel, Maggie Tulliver, in her quest of self-identification in the $19^{\text {th }}$ century conservative and patriarchal English society. Having failed in winning the support of Tom and her parents, her passionate wayward nature controls her and her smart abilities leads her into constant opposition with her family and the community. This article questions her ability to get out of the dangerous whirl the clash sends her inwith a destiny painfully played out in her relationships with three antagonist elements: Tom, her conservative and stubborn brother, Philip Wakem the son of her family's arch enemy, and Stephen Guest her suitor.

\section{TheOretical FrameWORK}

In the matter of gender approach, it is useful to deal with psychoanalytic theory in order to cope with girls' psychology that Eliot has dealt with in her novels. According to Historicism theory, the developments follow an organic succession of social conditions that affect or influence the final results significantly as Maggie's life is impacted. Historicism focuses on the historical aspects of all human existence. With regards to what happens to the protagonist of the novel, this theory seems appropriate. Moreover, the quest of coherency with Eliot's work under study induces me to apply literary criticism.

\section{THE POWER OF IMAgination}

In The Mill on the Floss, the movement and depth of the river floss suggest the progression not time and the growth of Maggie's conscious discoveries about life. The movement of the novel seems to point to the sublime and immutable power of the mind.

At the end of the novel, Maggie's imagination, dreams, and visions of fulfilment coalesce with her memories to produce in her a powerful recognition of truths. Maggie discovers that, in denial and the accompanying pain, one may find a power born of insight which will allow one to bear, to see, and to comprehend more fully one's misfortune and that of others in the clear light of dispassionate reason.

\section{THE REPRESSION}

Although we applaud Maggie's courage when she returns to the mill, we feel regret at the end of the novel which is due to the terrible sense of lost possibilities we feel for her. Throughout the novel, the 
narrator has subtly influenced our attitudes toward Maggie's high spirited temperament so that we admire her and regret the repression she experiences. The narrator shapes our reactions to Maggie by implying her approval of Maggie's imagination and its possibilities by use of contrast: George Eliot shows use Maggie's dull unimaginative mother (who encourages Maggie's passivity when she adopts the philosophy she finds in Thomas a Kempis), and she describes Tom as having.

"Clear, prosaic eyes, more apt to be dimmed by the mists of feeling or imagination" "Maggie is called spitfire. The contrast is clear, but the dilemma Maggie faces is subtle. She, with the wild gypsy's eyes, is faced with a life totally barren of "romantic vision" if she succumbs to the torpor she feels all around her. Throughout the novel, Eliot subtly cutinizes natures like Tom's which have 'no vision beyond the distinctly possible, and yield an existence, we are to fell, like that of waking dead, like ordinary adulthood, which is a "sordid life... irradiated by no sublime, principles, no romantic vision, no active, self-renouncing faith-moved by none of those wild, uncontrollable passion which....(Give) ... poetry to peasant life, 3

George Eliot begins her novel by "remembering, and in so doing she emphasizes the beauty in what is "natural".

The familiar flowers, these well-remembered, this sky with its fitful brightness, these furrowed and grassy fields, each with a sort of personality given to it by capricious hedgerows... such things as these are the mother tongue of our imagination. ${ }^{3}$

\section{THE NATURE}

The narrator stresses Maggie's communion with the natural world which makes her unique and gives her imagination of its life. One of Eliot's main concerns in this novel has to do with the "natural" development of Maggie's imaginative power to their ultimate good, which involves the expectation (as Eliot implies early in the novel) that Maggie's 'need for being loved, the strongest need in poor

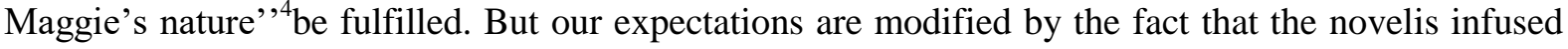
with poetic imagery, one of the most recurrent images being that of the force of the flow of the river which indicates the onrush of time and the mutability of all things. Our sense of progressing time and the fragile nature of human attachments create the tension in Eliot's narrative.

Eliot's depiction of the world around Maggie is that of an Eden gone bad, a place where adulthood experience of the world and its accompanying disillusionment create narrowly prescribed social guide lines which serve to break people's spirit and make them unnatural. Because Maggie received the wrong signals from her family, she suppresses her dreams and fantasies for a time when her father, her only ally, loses everything and becomes insensate, Maggie feels compelled to deny the reality of her hopes and dreams when she needs them most.

It is here that we realize that Philip Wakem's voice is the voice of wise counsel. Philips, who is a live embodiment of the idea that one's mental life can be one's salvation, tells Maggie that her fascination with self-denial is deadly and dangerous because it is a denial of her past, of who she really is, and of what she can realistically hope to endure. He tells her that:

On one has strength given to do what is unnatural. It is mere cowardice to seek safety in negations. No character becomes strong in that way. You will be thrown into the world some day, and then every rational satisfaction of your nature that you deny now will assault you like a savage appetite

Further, it is significant that Eliot places Maggie's fascination with mysticism, quietism, and renunciation after the scene with the Mumps and Bob, whose imagination, though uniformed, allows him the freedom to live simply and innocently, talking to Mumps as if it were a person and playing "knight in armour", 5 to Maggie's fair maiden. Since Maggie embodies the "'hurry of an imagination that could never rest, ${ }^{, 5}$ Bob's delightful rustic presence reinforces for us the value of the simple pleasures that we know Maggie should not renounce.

\footnotetext{
${ }^{1}$ George Eliot, The Mill on the Floss, Everyman's Library, London 1964.Book IV, ch2.

${ }^{2}$ Ibid. Book, IV, ch. 1

${ }^{3}$ Ibid. Book, V, ch. 2

${ }^{4}$ Ibid. Book, I, ch.5

${ }^{5}$ Ibid. Book, IV, ch. 3
} 
As Philip predicted, Maggie loses control of her imagination for a time at Lucy's when she « expands unrestrainedly in the warmth of the present $»^{6}$ as a result of unnatural repression, but when Maggie regains an awareness of her responsibilities and leaves Stephen, she does so because she remembers the past. She regains a sense of humility and recognition of her limitations. And later Eliot tells us that Maggie carries within her «the memory of her child's feeling a memory that was always strong in her $»^{7}$. Therefore, when she is with Stephen, she can eventually envision, as she did as a child, « hungry lions ready to leap $»^{8}$, and she exercises her imagination enough to see that continuing to act out of a blind appreciation of the present will hurt others and to do irreparable damage to the image of herself. It is ironic that by facing her weaknesses, she finds her strength. Maggie returns to the mill. But she can never really go back in time. The past is lost, and the tide keeps rushing forward. All things are mutable except memories and, perhaps, dreams. Maggie ask Stephen, if the past is not bind us, where can duty lie? We should have no law but the inclination of the moment.

Maggie is in many ways more like Philip than other character in the novel because she likes Philip, feels a constant longing for fulfilment born from the "power of love ${ }^{9}$. Sometimes, after the rabbits die, Maggie tells Phillip, «I never forget anything » ${ }^{10}$.

\section{THE PASSION}

If Maggie had not suppressed her real nature, if she had not lied to herself about who she really was, she would have felt, like Philip, a " repulsion towards worldliness and deliberate pursuit of sensual enjoyment for its own sake "11. This kind of balanced passion, which, because it is contained in the mind, is synonymous with strength and power.

Maggie dies young; yet she seems to have recognized and assimilated before she dies the fact that she could not deny her past and renounce the passion and imagination that make her the person she is and still expect to be fulfilled. Maggie's imaginative powers allow her to achieve a delicate balance between exuberance and restrain, a balance, which, according to Eliot, is clearly not total renunciation, that it is not resignation hat it is not inaction and that is not the death of hope. Eliot attitude is made clear in the contrast she creates between Maggie and the other characters and in her narrative tone: At least Maggie dies during a struggle. In witnessing Maggie's life appreciating her struggle, we see that Maggie, even in her trip with Stephen, was the best person she could have been, given a world in which she was encouraged not to dream.

The fact that at the end of the novel Maggie's consciousness reses « once more in strength » makes us regret all the more intensely Maggie's loss of possibilities. They remain «evermore about to be », fixed in art, just as the hopes and expectations of Keats' figures on the urn. Philip's last letter to Maggie describes what his love for her has done for him, but it could also describe what Maggie's love for Stephen accompanied by her memories has done for her:

you have raised a dim unrest a vivid consciousness. The new life I have found in caring for your joy and sorrow more than for what is directly my own, has transformed the spirit of rebellious murmuring into that willing endurance which is the birth of strong sympathy. I think nothing but such complete and intense love could have initiated me into that enlarged life which grows and grows by appropriating the life of others: for before, I was always dragged back from it by ever - present painful self - consciousness. I even think sometimes that this gift of transferred life which has come to me in loving you, may be a new power to me... The place where you are is the one where my mind must live, wherever I might travel. ${ }^{12}$

This passage contains the sad and inspiring essence of The Mill on the Floss. Maggie returns to the mill on the strength supplied to her as the result of a long turbulent process of discovery: her « dim unrest », like Philip's transforms into a conscious, quiet, and powerful recognition of the complexity involved in reconciling her unfulfilled, longing, and yearning imagination with the reality of her pa

\footnotetext{
${ }^{6}$ Ibid. Book, VI, ch. 10

${ }^{7}$ Ibid. Book, V, ch. 1

${ }^{8}$ Ibid. Book, I, ch.5

${ }^{9}$ Ibid. Book, VI, ch. 14

${ }^{10}$ Ibid. Book, II, ch. 4

${ }^{11}$ Ibid. Book, II, ch. 6

${ }^{14}$ Ibid. Book, VII, ch. 3
} 


\section{CONCLUSION}

The fury of Maggie's struggle seems to yield an anticlimactic result because of the contrast between the passion in her struggle and the intellectual quite and momentary immediacy of her insight. George Meredith starkly and poignantly characterizes this kind of paradox in the last stanza of «Modern Love »:

Ah, what a dusty answer gets the soul

Where lost for certainties in this our life!

In tragic hints here see what evermore

Moves dark as yonder midnight ocean's force,

Thundering like ramping hosts of warriot horse

To throw that faint thin line

Upon the shore. ${ }^{13}$

Eliot recognized the turmoil one must experience to glimpse that faint thin line; yet she seems to equate the strength on one's spiritual resilience with intensity of pain and with the power of one's imagination, insight, and «amplitude of mind», and, at the end of The Mill on the Floss, we are left with an urgent sense of what Maggie passionately dreamed of having in contrast to what she got. Although we are comfortable when Maggie dies, Eliot creates in her death a keener impression for us of an ideal. The final effect of Maggie's death is that recognize the forceful and immutable power of the imagination, reawakened by passionate love and restrained by vivid memories, longing and yearning for something more in the mundane, temporal world.

\section{REFERENCES}

\section{Books}

[1] Eliot, George The Mill on the Floss. Every man's Library, London 1964

[2] Freishman, Avrom. George Eliot'sIntellectual Life. Cambridge UniversityPress, 2010.

[3] Haight, Gordon. George Eliot : Biography; Oxford University Press, 1968

[4] Meredith, George, "Modern Love" and Poems of the English Roadside, with Poems and Ballads, Chapman \& Hall, 1862, edited by E. Cavazza, Mosher, 1891

[5] Wordsworth, William, The Prelude : Selected Poems and Sonnets. Macmillan Press, London 1984.

\section{Reviews and Magazines}

[1] Paris, Bernard, 'Toward a Revaluation of George Eliots'sThe Mill on the Floss'" in Nineteenth Century Fiction, Paris, ed.2016

[2] Thale Jerome, 'Image and Theme: The Mill on the Floss " in University of vansers city Review, 1957.

[3] Smith, David, "Incest Patterns in Two Victorians Novels "in Literature and Psychology, London, new ed.2017

\section{Websites}

https://searchcio.techtarget.com/definition/leadership at 00h 08 am on 28/08/2018

https://www.philosophybasics.com/branch_historicism.html at 00h 08 am on 28/08/2018

Citation: Ibrahim Yekini. "The Narrative Emphasis on the Power of the Imagination in The Mill on the Floss: A Critical Analysis" International Journal of Humanities Social Sciences and Education (IJHSSE), vol 6, no. 1, 2019, pp. 1-4. doi: http://dx.doi.org/10.20431/2349-0381.0601001.

Copyright: () 2019 Authors. This is an open-access article distributed under the terms of the Creative Commons Attribution License, which permits unrestricted use, distribution, and reproduction in any medium, provided the original author and source are credited.

\footnotetext{
${ }^{13}$ George Meredith, 'Modern Love", and Poems of the English Roadside, with Poems and Ballads, Chapman \& Hall, 1862
} 